\title{
Groundwater Conservation Strategy Based on Water Balance at Muarabungo Groundwater Basin, Indonesia
}

\author{
Mochamad Nursiyam Barkah ${ }^{1}$, Fauziyah Hani ${ }^{2}$, Bombom Rachmat Suganda ${ }^{1}$, \\ Munib Ikhwatun Iman ${ }^{3}$, Cecep Yandri Sunarie ${ }^{1}$, Mohamad Sapari Dwi Hadian ${ }^{1 *}$ \\ ${ }^{I}$ Water Center Geology Faculty, Padjadjaran University, Jatinangor 45363, Indonesia. \\ ${ }^{2}$ Magister Program, Fakulty of Geology, Padjadjaran University, Jatinangor 45363, Indonesia. \\ ${ }^{3}$ Center for Groundwater and Environmental Geology, Geological Agency MEMR, Bandung, Indonesia.
}

* Corresponding author : sapari@unpad.ac.id

Tel.: +62-81321102268; fax: +62-22-7796545 [Tel./fax]

Received: Oct 16, 2019; Accepted: Jun 20, 2021.

DOI: $10.25299 /$ jgeet.2021.6.3.3976

\section{Abstract}

Muarabungo Groundwater Basin,is locateed in Jambi and West Sumatra Province. Based on the four rainfall stations in Muaratebo, Dusun Rantau Pandan, Sungai Bengkal and Komplek Pengairan PU Station recorded in 2008 to 2011, the precipitation (ppt) in study area is 1799.09 $\mathrm{mm} /$ year. Value of evapotranspiration (Evpt) in the study area is equal to $1261.26 \mathrm{~mm} /$ year $(70.1 \%)$. Groundwater Basin of Muarabungo has an infiltration debit of 2,516,791,750 m3 / year and run-off debit (Ro) of $798042638 \mathrm{~m} 3$ / year. Rock composer in the Muarabungo Groundwater Basin are dominated by Alluvium Deposition, Quaternary rocks, and also the surrounding areas are composed by igneous and metamorphic rocks. Aquifer with a good productvity can be found on Alluvium and sedimentary rocks such as tuff sandy, whereas region without exploitable groundwater are composed by igneous rocks and metamorphic rocks. Based on groundwater quality, Groundwater Basin is divided into 13 facies, namely $\mathrm{Ca} ; \mathrm{Cl}, \mathrm{Mg} ; \mathrm{Cl}, \mathrm{Na}+\mathrm{K}, \mathrm{Cl}, \mathrm{Ca} ; \mathrm{HCO} 3, \mathrm{Mg} ; \mathrm{HCO} 3, \mathrm{Na}+\mathrm{K} ; \mathrm{HCO}$, Ca; No. dominant type, Mg; Nodominan type, Na + K; No. dominant type, No. dominant type; $\mathrm{Cl}$, No. dominant type; HCO3, Nodominan type; SO4, and No. dominant type; No. dominant type. The result of water balance measurement in research area is used to show the areas for crisis and secure area. The water balance calculation and determining recharge and discharge areas are needed for developing conservation strategy.

Keywords: Groundwater Basin, water balamce, aquifer, conservation, Muarabungo

\section{Introduction}

The population in Indonesia increased each year, including the Jambi Province. This in turn drive the high demand for clean water sourced from ground water. For ground water utilization, it must be known in advance the potential of ground water in the Muarabungo basin, both based on quantity and quality. Due to the groundwater use, groundwater basin potential must be balance with conservation efforts in order that optimal utilization and prevent environmental disaster such as groundwater depletion, flood in rainy season, and drought in dry season. Therefore, the potential of groundwater in each region is very important to know both the quantity and quality in determining an effective groundwater conservation strategy so that the sustainability of groundwater utilization will be guaranteed in the future.

\section{Research Method}

The research method uses primary data supported by secondary data. The data comes from government agencies such as Water Resources Research Center and Development (PUSAIR), Statistic Center Agency (BPS), literature studies, and the Geological Agency. These data include, geological maps, hydrogeological maps, topographic maps, land use maps, rainfall data, climatology data, water use data, and population data. In addition there are data on the physical and chemical properties of groundwater in the study area. From the available data, the water balance is calculated using the Ffolliott method and groundwater quality is also determined from an analysis of the physical and chemical properties of the groundwater (Folliott, Baker, Tecle, \& Neary, 2003). From the quantity and quality, the conservation strategy is determined at an altitude of 42 - 133 meters.

In general, groundwater is relatively acidic, possibly due to various factors. It could be due to water contact with the rocks that pass through it namely rocks from the Kasai Formation which consists of tidal rock rocks are acidic, tuff sandstones, with bentonite inserts and little lignite or due to acid rain due to air waste from coal mining.

The following results of the analysis of the physical properties of groundwater in Muarabungo Groundwater Basin:

Table 1. Analisys of Physical Properties Results of Water in Muarobungo Groundwater Basin Area

\begin{tabular}{|c|c|c|}
\hline Physical Properties & $\begin{array}{l}\text { Measurement } \\
\text { Result }\end{array}$ & Notes \\
\hline Water Temperature & $26.2^{\circ} \mathrm{C}-31.7^{\circ} \mathrm{C}$ & - \\
\hline $\mathrm{pH}$ & $4.2-8.8$ & $\begin{array}{l}\text { Poor - Good Quality } \\
\text { (Dephut, 2009) }\end{array}$ \\
\hline $\begin{array}{c}\text { Electrical } \\
\text { Conductivity }\end{array}$ & $0-340 \mu \mathrm{S} / \mathrm{cm}$ & $\begin{array}{l}\text { Fresh Groundwater } \\
\text { (Mandel, 1981) }\end{array}$ \\
\hline $\begin{array}{c}\text { Dissolved Solids } \\
\text { Total }\end{array}$ & $0-150 \mathrm{mg} / \mathrm{l}$ & $\begin{array}{l}\text { Fresh Groundwater } \\
\text { (Freeze \& Cherry, } \\
\text { 1979) }\end{array}$ \\
\hline
\end{tabular}

Groundwater chemical analysis was carried out at 54 points of interest. Groundwater quality was determined based on PP RI No. 20 of 1990 concerning Water Quality Criteria and SK. Men KLH No: Kep-02 / MENKLH / I / 1988 concerning Water 
Quality Standards for Water Resources and Groups A and B and based on the Republic of Indonesia Ministerial Regulation Number 492 / MENKES / PER / IV / 2010 Concerning

Table 2. Comparison of Water Quality Based on Standards of Quality Standards and Field Conditions

\begin{tabular}{llll}
\hline \multicolumn{1}{c}{ Element } & \multicolumn{1}{c}{ Measurement Result } & \multicolumn{1}{c}{ Max. Water Quality Standard } & Notes \\
\hline $\mathrm{Ca}$ & $0-26.7 \mathrm{mg} / \mathrm{l}$ & $200 \mathrm{mg} / \mathrm{l}$ & Good Quality \\
$\mathrm{Mg}$ & $0.03-10.835 \mathrm{mg} / \mathrm{l}$ & $150 \mathrm{mg} / \mathrm{l}$ & Good Quality \\
$\mathrm{Na}$ & $0.33-14.55 \mathrm{mg} / \mathrm{l}$ & $200 \mathrm{mg} / \mathrm{l}$ & Good Quality \\
$\mathrm{Cl}$ & $0.97-18.5 \mathrm{mg} / \mathrm{l}$ & $250 \mathrm{mg} / \mathrm{l}$ & Good Quality \\
$\mathrm{SO}_{4}$ & $0-14.46 \mathrm{mg} / \mathrm{l}$ & $100 \mathrm{mg} / 1$ & Good Quality \\
$\mathrm{HCO}_{3}$ & $2.49-112.7 \mathrm{mg} / \mathrm{l}$ & - & - \\
$\mathrm{K}$ & $0.1-9.86 \mathrm{mg} / \mathrm{l}$ & - & - \\
\hline
\end{tabular}

\section{Groundwater Facies}

Based on groundwater chemical data, groundwater facies were determined the study area development. The data is plotted to the Piper diagram (Figure 1). Plotting data into piper diagrams is assisted with rockworks15 software. From the results of the analysis of groundwater facies in the study area
Drinking Water Quality Requirements. Here are the results of measurements of water samples: (M. S. D. Hadian \& Rahmat, 2015)

can be divided into 13 groundwater facies, namely the facies of $\mathrm{Ca} ; \mathrm{Cl}, \mathrm{Mg} ; \mathrm{Cl}, \mathrm{Na}+\mathrm{K} ; \mathrm{Cl}, \mathrm{Ca} ; \mathrm{HCO} 3, \mathrm{Mg} ; \mathrm{HCO} 3, \mathrm{Na}+\mathrm{K}$; $\mathrm{HCO} 3, \mathrm{Ca}$; No dominant type, $\mathrm{Mg}$; No dominant type, $\mathrm{Na}+\mathrm{K}$; No dominant type, No dominant type; $\mathrm{Cl}$, No dominant type; HCO3, No dominant type; SO4, and No dominant type; No dominant type. (M. S. D. Hadian, Prayogi, \& Azy, 2012)

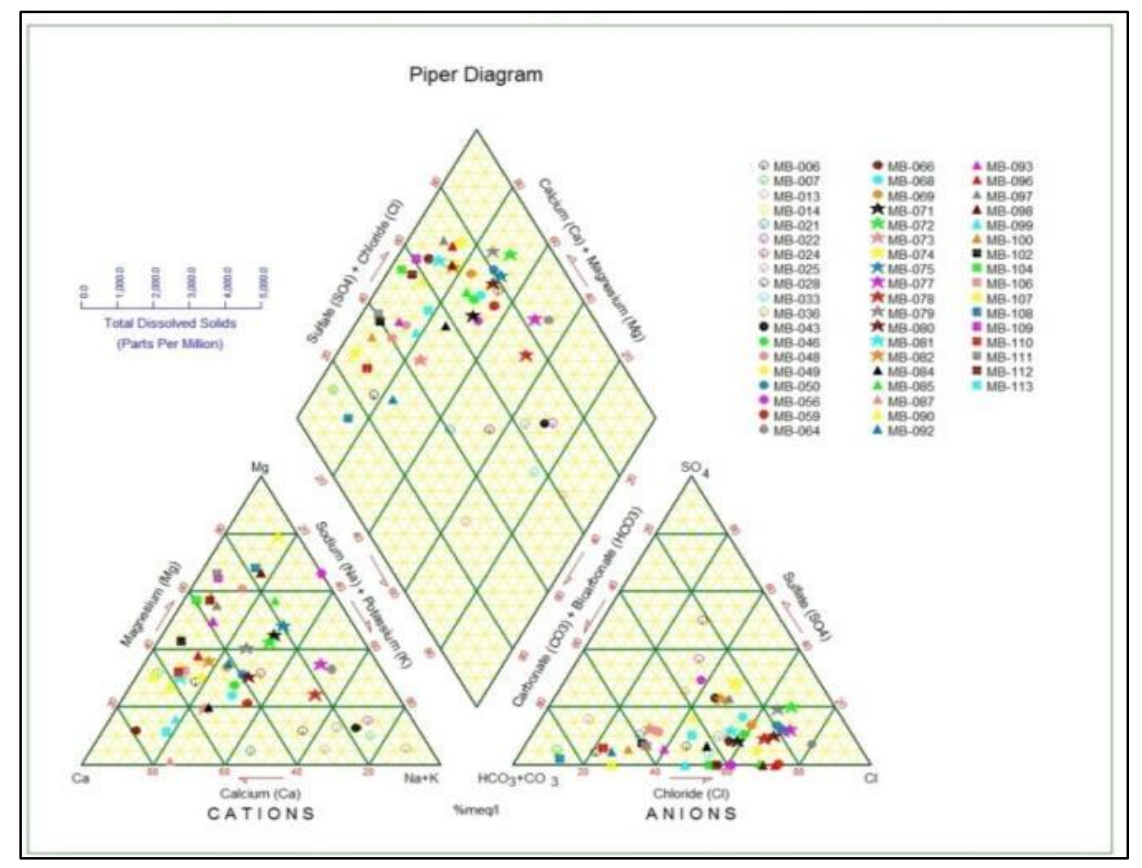

Fig 1.Results of groundwater chemical data plots into the Piper diagram

\section{Discussion}

Groundwater conservation is an effort to protect and maintain the condition and environment of the groundwater in order to maintain the sustainability or continuity of the availability in adequate quantity and quality, for the sake of the continuity of its functions and benefits to meet the needs of living things, both now and in future generations (Danaryanto \& Darmawan, 2004, Kodoatie, Robert J. \& Syarief, 2010). Groundwater conservation efforts that can be done at the Muarabungo Groundwater Basin include:

\subsection{Groundwater Preservation}

Groundwater preservation means groundwater extraction is limited to a safe amount, where the water uptake must be adjusted to the potential of available water and also does not cause negative impacts on the environment, such as the impact of groundwater level degradation $791,750 \mathrm{~m} 3$ / year.

However, not all the potential water available can be extracted and used for daily needs. Therefore infiltrated water below the surface not only fill the aquifer, but also fill the unsaturated zone (unsaturated water) and the saturated zone (saturated water).

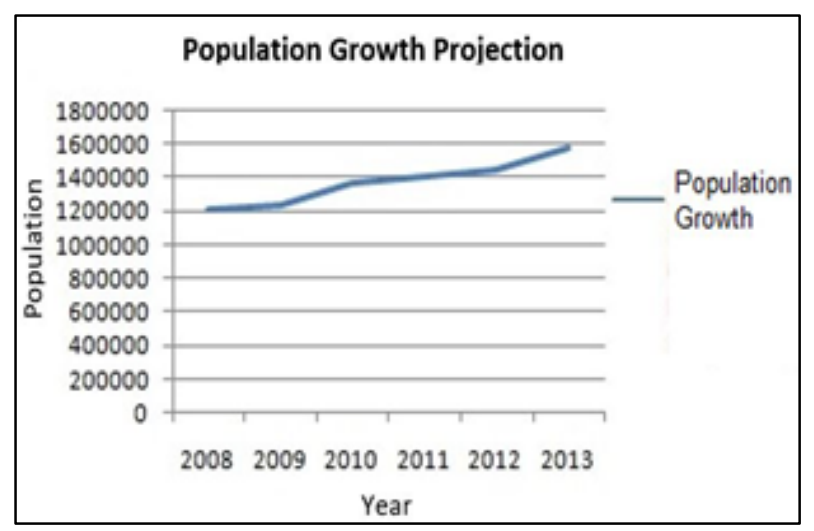

Fig 2. Population Growth in Muarabungo Groundwater Basin 
Specific yield is the ratio in percent $(\%)$ of the volume of water that can be taken from a soil or rock that is saturated with water compared to the total volume of rock or soil. This specific yield is a large amount of water available for human use. According to Todd (1980), Sy alluvium which consists of clayrich material is $3-28 \%$, Sy sandstones $21-27 \%$, and Sy tuff $21 \%$. The Muarabungo Groundwater Basin is dominated by alluvium and sandy tuff / sandstone tuff, so that each region is not permitted to use water exceeding $28 \%$ of the total water potential that is equal to $704,701,690 \mathrm{~m} 3$ / year.



Fig 3. Estimated Groundwater Use Lines
Based on the Figure 3, the amount of water usage (domestic water demand), predicted to reach a critical figure around 2030, assumed based on the average population growth results in 2008-2013 (Source: BPS) which is 5.5\%. The critical limit for water use is $28 \%$ of the potential water available. The amount of water used is only based on domestic water needs. This projection is only based on population growth, not yet projected by the influence of land use change. If the amount of groundwater use coupled with industrial and commercial needs and the effect of increasing runoff water coefficients are included, it is possible that critical water estimates will occur before 2033. Therefore, to avoid this happening, conservation must continue.

\subsection{Determination of groundwater catchment areas}

The determination of groundwater catchment areas is intended to be designated as a protected area by the local government. In accordance with Law Number 24 of 1992 concerning Spatial Planning and Presidential Decree Number 32 of 1990 concerning the Protection of Protected Areas is explicitly stated that water catchment areas are designated as protected areas where any cultivation activities are prohibited in those areas unless they do not disturb the protection function (M. Hadian, Mardiana, Abdurahman, \& Iman, 2006). The function of water catchment areas is to supplement groundwater reserves. In this study, the water catchment area was determined based on buckling slopes (boundary morphology of the land with hills), the position of the emergence of springs, depth of ground water level, Ec and TDS values.



Fig 4. Recharge and Discharge Zone Map

\subsection{Addition of groundwater recharge (artificial recharge)}

If groundwater utilization is increased, the groundwater refilling capacity can be artificially enlarged. Addition of groundwater recharge can be done by making rainwater collection ponds or catchment wells. The addition of groundwater recharge such as recharge wells generally can be applied to areas with high groundwater uptake with high population density areas from the surrounding area namely Kec. Pasar Muarabungo with a density of 2,631.13 inhabitants $/ \mathrm{km}^{2}$ (BPS Bungo District, 2013). Wells infiltration aim to increase water infiltration in open areas such as fields, parking lots, yards and so on. Furthermore the construction and depth adapted to local soil conditions.
Rainwater collection ponds are ponds or containers used to collect rainwater. This method can be applied in the area around the Muaratebo Station and Bengkal River because it is noted that the rainfall in this area is smaller than other stations it can be seen in Figure 2. The main objective is to raise the groundwater level, and also to store excess water reserves when it rains, so that there are water reserves during the dry season. This method has a direct effect on free groundwater in the shallow aquifer layer, and is effective for replenishing water into the deep aquifer layer.

\subsection{Public Outreach}

Some people's misunderstanding about all matters relating to groundwater sometimes makes groundwater users not pay 
attention to the conservation of groundwater, such as disposal of household waste and disposal of sewage (feces) that do not meet the requirements and that can pollute groundwater. Therefore the understanding of groundwater resources and the proper use of groundwater needs to be socialized to the community in this groundwater conservation effort.

\section{Conclusion}

Based on water balance calculations, all areas in the Muarabungo Groundwater Basin are still in a safe zone, there are no crisis areas. This area has underground water potential of 2,516,791,750 m3 / year and surface water of 798,042,638 m3 / year. The assumption of water use in the Muarabungo Groundwater Basin is 29,565,821.25 m3 / year. Based on the physical and chemical properties of groundwater, groundwater quality in the Muarabungo Groundwater Basin is quite good. It's just that the $\mathrm{pH}$ value in some places is quite acidic. Conservation strategies that can be carried out include:

- Groundwater preservation Intake of water must be adjusted to the potential of available water. Potential water availability is $768,476,816.75 \mathrm{~m} 3$ / year - Determination of Groundwater Absorption Areas

Based on the analysis results, the recharge area is estimated to be in Kec. Punjung Island, Tabah,.

Padang Laweh, Jujuhan, Tanah Tumbuh, Tanah Sepenggal, Maro Sebo Ulu, and Muara Tabir.

- Addition of groundwater additives (artificial recharge)

Addition of groundwater recharge can be done in areas with high population density. The highest population density in the study area is in Pasar Muarabungo District, which is 2,631.13 people / km2 (BPS Bungo District, 2013).

- Community Outreach

This is done so that the community understands about all matters relating to groundwater so that in the implementation of groundwater utilization so that the community can pay attention to the conservation of groundwater.

\section{Acknowledgement}

The authors thank the Unpad Postgraduate School Dean Prof. Dr. Hendarmawan, M.Sc, Head of the Environmental Geology Laboratory, Faculty of Geological Engineering, Padjadjaran University, Rudi Suhendar Head of the Geology Agency who has facilitated all needs and provided the data needed for the purposes of this research.

\section{References}

Danaryanto, S., \& Darmawan, H. (2004). Air tanah di Indonesia dan pengelolaannya. [Jakarta]: Departemen Energi dan Sumber Daya Mineral Indonesia.

Ffolliott, P. F., Baker, M. B., Tecle, A., \& Neary, D. G. (2003). A Watershed Management Approach to Land
Stewardship. Journal of the Arizona-Nevada Academy of Science.

Hadian, M., Mardiana, U., Abdurahman, O., \& Iman, M. . (2006). Sebaran akuifer dan pola aliran air tanah di Kecamatan Batuceper dan Kecamatan Benda Kota Tangerang, Propinsi Banten. Indonesian Journal on Geoscience, 1(3), 115-128. https://doi.org/10.17014/ijog.vol1no3.20061

Hadian, M. S. D., Prayogi, T. E., \& Azy, F. N. (2012). Groundwater Quality Assessment for Suitable Drinking and Agricultural Irrigation Using Physico-Chemical Water Analysis in the Rancaekek- Jatinangor District, West Java, Indonesia. International Proceedings of Chemical, Biological and Environmental Engineering.

Hadian, M. S. D., \& Rahmat, B. (2015). Manajemen air tanah pada endapan aluvium geologi dan hidrogeologi Daerah Rawa Lakbok, Jawa Barat. Bulletin of Scientific Contribution, 13, 192-201.

Kementrian Kehutanan. 2013. Peta Penggunaan Lahan Indonesia Tahun 2012, Lembar 0814, Painan, Provinsi Sumatera Barat. Kementrian Kehutanan

Kementrian Kehutanan. 2013. Peta Penggunaan Lahan Indonesia Tahun 2012, Lembar 0815, Solok, Provinsi Riau. Kementrian Kehutanan

Kementrian Kehutanan. 2013. Peta Penggunaan Lahan Indonesia Tahun 2012, Lembar 0914, M. Bungo, Provinsi Jambi. Kementrian Kehutanan

Kodoatie, Robert J. \& Syarief, R. (2010). Tata Ruang Air Tanah. Yogyakarta: Andi Press.

Purwanto, dkk., 1983. Peta Hidrogeologi Indonesia Lembar 0815 Solok. Badan Geologi. Bandung

Rosidi, dkk., 1996. Peta Geologi Lembar Panian dan Bagian Timur Lembar Muarasibeurit, Sumatera

Setiawan, dkk., 2013. Peta Hidrogeologi Indonesia Lembar 0914 Muarabungo. Badan Geologi. Bandung

Simandjuntak, dkk. 1994. Peta Geologi Lembar Muarabungo, Sumatera. Badan Geologi. Bandung

Soetrisno, dkk., 1987. Peta Hidrogeologi Indonesia Lembar 0714 Muarasibeurit sebagian Lembar 0814 Painan. Badan Geologi. Bandung

Sosrodarsono dan Takeda. 2003. Hidrologi untuk Pengairan. Jakarta : Paradnya Paramita

Todd, D. K. (1980). Groundwater Hydrology. (J. Willey, Ed.) (2nd Editio). Wiley, New York. https://doi.org/10.1002/gj.3350170407

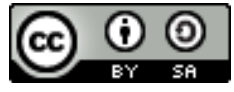

(C) 2021 Journal of Geoscience, Engineering, Environment and Technology. All rights reserved. This is an open access article distributed under the terms of the CC BY-SA License (http://creativecommons.org/licenses/by-sa/4.0/). 